\title{
PERBANDINGAN KAPASITAS KUAT LENTUR PADA BETON BALOK TULANGAN BAMBU PILIN DENGAN KULIT DAN TANPA KULIT
}

\author{
Angga Dwi Cahya*1, Yosef Cahyo S.P ${ }^{2}$, Ahmad Ridwan ${ }^{3}$. \\ ${ }^{1,2,3}$ Fakultas Teknik, Universitas Kadiri. \\ e-mail:*1anggadwicahya03@gmail.com,2yosef.cs@unik-kediri.ac.id. \\ 3ahmadridwan@unik-kediri.ac.id.
}

\begin{abstract}
We all know that steel elements cannot be renewed and their constituent elements take a long time to form. So there is a need for other alternatives which have steellike properties. One alternative is bamboo, bamboo is one material that can be used as a substitute for steel, because bamboo has a high tensile strength close to the strength of steel. In this study an attempt was made to compare the use of reinforcement with bamboo on the outside with the skin and the inside without skin to determine the flexural strength. The flexural strength test results on variations of skin obtained the value of Max P: average: $3400 \mathrm{~kg}$ with an average deflection of $9.25 \mathrm{~mm}$ while in variations without the skin $P$ Max produced an average of $2400 \mathrm{~kg}$ with deflection value of $1.92 \mathrm{~mm}$.
\end{abstract}

Keywords : $\quad$ Bamboo Skin, Skin Variation, Flexural Strength, Max P, Crack Pattern

\begin{abstract}
Abstrak
Kita ketahui bersama bahawa unsur baja tidak bisa diperbaharui serta unsur penyusunnya yang membutuhkan waktu yang lama untuk terbentuk. Sehingga perlu adanya alternatif lain yang dimana memiliki sifat menyerupai baja. Salah satu alternatifnya adalah bambu, bambu merupakan salah satu bahan dapat digunakan sebagai pengganti baja, karena bambu mempunyai kuat tarik yang tinggi yang mendekati kekuatan baja. Pada penelitian ini dicoba untuk membandingkan penggunaan tulangan dengan bambu bagian luar dengan kulit dan bagian dalam tanpa kulit guna mengetahui kekuatan lentur. Hasil pengujian kuat lentur pada variasi kulit didapatkan nilai P Maks: rata-rata:3400 kg dengan lendutan rata-rata 9.25 mm sedangkan pada variasi tanpa kulit P Maks rata-rata yang dihasilkan $2400 \mathrm{~kg}$ dengan nilai lendutan $1.92 \mathrm{~mm}$.
\end{abstract}

Kata Kunci : Kulit Bambu, Variasi Kulit, Kuat Lentur, P Maks, Pola Retak 


\section{PENDAHULUAN}

Kita ketahui bersama bahawa unsur baja tidak bisa diperbaharui serta unsur penyusunnya yang membutuhkan waktu yang lama untuk terbentuk. Sehingga perlu adanya alternatif lain yang dimana memiliki sifat menyerupai baja [1]. Salah satu alternatifnya adalah bambu, bambu merupakan salah satu bahan dapat digunakan sebagai pengganti baja, karena bambu mempunyai kuat tarik yang tinggi yang mendekati kekuatan baja. Merujuk pada penelitian sebelumnya yang berjudul Penerapan bambu sebagai tulangan dalam struktur rangka batang beton bertulang [2][3].

Pemakaian bambu pada tulangan beton perlu perlakuan khusus, karena kerap kali dalam pembangunan menemui kesulitan, "seperti permasalahan pada lekatan antara bambu dan semen yang kurang baik, kemudian sifat bambu yang higroskopis yang memengaruhi kembang susut yang berpengaruh pada lekatan antara bambu dan beton "[2][4][5]. Maka dari itu perlu dilakukan pilinan guna mengatasi masalah lekatan antar tulangan dan beton itu. Pada kesempatan kali ini peneliti mencoba untuk mengamati lebih lanjut bagaimana penggunaan balok beton dengan menggunakan bambu pilin. Yang dimana dalam analisa penelitian ini hasilnya difukoskan pada seberapa kuatannya nilai lentur maksimum pada balok yang menggunakan bambu pilin yang digunakan sebagai tulangan balok beton.

\section{METODE PENELITIAN}

\subsection{Lokasi Penelitian.}

Penelitian ini dilakukan di Laboratorium Teknik Sipil Universitas Kadiri, pada awal bulan maret dan selesai pada bulan juni dengan menggunakan metode Eksperimen.

\subsection{Bahan Punyusun Beton}

Beton adalah" sebuah bahan bangunan komposit yang terbuat dari kombinasi agregat dan pengikat semen. Beton merupakan campuran antara semen Portland atau semen hidraulik yang lain, agregat halus, agregat kasar dan air, dengan atau tanpabahan tambahan yang membentuk masa padat" [6][7]. Beton memiliki nilai daktilitas yang tinggi dan memiliki kuat tekan yang tinggi dibandingkan kuat tariknya. Nilai kuat tarik beton berkisar antara 9\% - 15\% dari kuat tekannya [8][9][10].

\subsubsection{Air}

Dalam pembuatan beton penggunaan air sangat diperlukan agar terjadi reaksi kimia dengan semen guna menyelimuti agregat guna mempermudah pengerjaan[11][12]. Air yang mengandung senyawa-senyawa yang bahaya, seperti air yang tercemar atau tercampur garam, minyak, gula, dan bahan kimia lain, bila dipakai untuk campuran beton makaakan sangat menurunkan 
kekuatannya dan juga dapat merubah sifat semen. Selain itu, air yang tercemar dapat mengurangi reaksi afinitas antara agregat dengan semen dan mungkin juga dapat mempengaruhi kemudahan pengerjaan [13][14].

\subsubsection{Semen}

"Semen merupakan jenis bahan yang memiliki sifat adesif (adhesive) dan kohesif (chohesive) yang menyebabkan lekatnya fragmen-fragmen mineral menjadi suatu massa yang padat. Komposisi semen portland pada umumnya terdiri dari kapur $(\mathrm{CaO})$ sekitar 60\%-65\%, silica (SiO2) sekitar 20\%-25\%, dan oksida besi serta alumina (Fe2O3 dan Al2O3) sekitar 7\%-12\%. Sedangkan oksida lain yang jumlahnya hanya beberapa persen dari berat semen berupa senyawa C3S, C2S, C3A, dan C4AF" "[15][16].

\subsubsection{Agregat}

\section{Agregat Halus}

Agregat yang lolos pada ayakan 4,8 mm. Agregat halus didominasi berupa pasir halus. Ukurannya bervariasi antara ukuran No.4 dan No.100 saringan yang berstandar SNI. Agregat halus yang baik harus berbahan baku organik, lempung, partikel yang lebih kecil dari saringan No.100, atau bahan-bahan lain yang dapat merusak campuran beton [8][17][18].

\section{Agregat Kasar}

Agregat Kasar (Kerikil) yaitu agregat yang ukuran butirannya semua tertinggal pada ayakan dengan lubang $4.8 \mathrm{~mm}$. Agregat ini bisa disebut agregat kasar pabila ukurannya lebih dari $1 / 4$ in $(6 \mathrm{~mm})$. Agregat kasar mineral harus benar-benar bersih dari bahan organik, dan harus memiliki ikatan yang kuat terhadap gel dan semen [19][20][21].

\subsubsection{Bambu}

Bambu merupakan tanaman sebangsa rumput yang banyak tumbuh di Indonesia. Bambu secara botanis dapat digolongkan pada family Graminese (rumput). Tanaman ini dapat tumbuh di daerah beriklim panas maupun dingin. Bambu merupakan tanaman jenis rerumputan dengan rongga dan ruas di batangnya. Bambu juga merupakan jenis tanaman yang pertumbuhan nya cepat. Dalam sehari bambu dapat tumbuh sekitar $60 \mathrm{~cm}$ bahkan lebih, tergantung pada kondisi tanah dan klimatologi tempat bambu tersebut ditanam.

\subsection{Runtutan Penelitian.}

Pada penelitian ini dilaksanakan di Laboratorium Teknik Sipil Fakultas Teknik Universitas Kadiri Kediri. Metode yang digunakan dalam penelitian ini adalah dengan uji lentur dan lendut, dalam penelitian “Morisco untuk mengetahui perbedaan kekuatan bambu dari bagian luar dan bagian dalam, maka dibuat specimen dengan bambu dibelah tangensial tebal sekitar 1/2 
dari bambu utuh. Bagian sisi yang ada kulitnya mewakili bambu bagian luar". Pada penelitian ini dicoba penggunaan Tulangan bambu petung. Langkah pertama sebelum digunakan adalah bambu dipisah antara yang kulit dan tanpa kulit setelah itu dipilin, langkah kedua bambu di rendam menggunakan cairan garan \pm 20 menit agar serbuk halus yang terdapat pada bambu lepas sehingga membuat bambu lebih elastic, jadi lebih mudah dipilin. Langkah ketiga yakni pada proses pemilinan pada bambu mennggunakan hasil pull out dengan pola 1. Langkah terakhir yakni setelah bambu dipilin kemudian tulangan bambu yang sudah dipilin tadi dilapisi sikadur lalu ditaburi pasir. Pada proses uji nilai kelenturan kali ini dipakai dua sampel tulangan yaitu bambu pilin dengan kulit dan tulangan bambu pilin tanpa kulit.

\section{HASIL DAN PEMBAHASAN}

\subsection{Pengujian Kuat Tekan Silinder}

Grafik 1. gabungan hasil kuat tekan

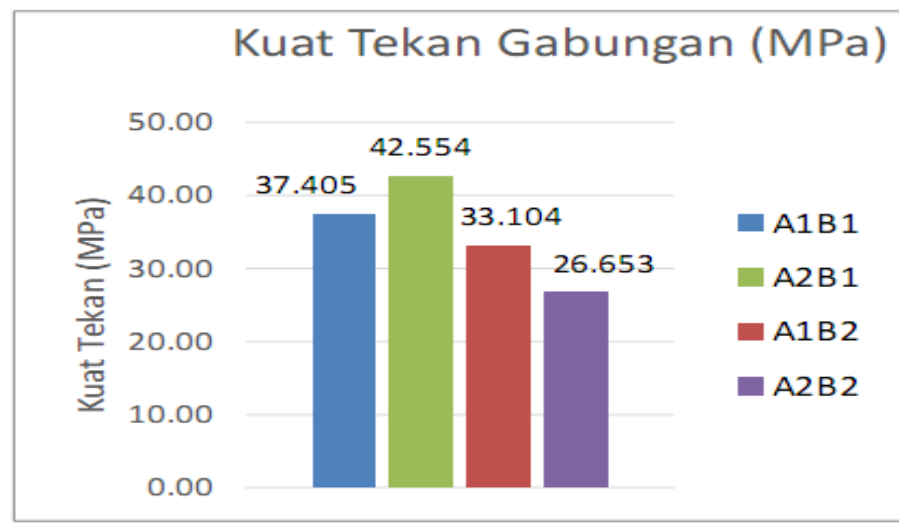

Sumber : Hasil perhitungan pengujian kuat tekan

Pada rafik diatas dapat dilihat hasil pengujian kuat tekan beton, terlihat hasil yang berbeda pada penggunaan variasi benda uji. penggunaan terbaik pada uhasil uji tekan diatas adalah pada benda uji A2B1 dengan nilai $42.554 \mathrm{Mpa}$ dan hasil yang kurang baik terdapat pada benda uji A2B2 yang dimana hanya memiliki nilai kuat tekan sebesar 26.663 Mpa.

\subsection{Uji Kuat Lentur}

Dalam uji kuat lentur balok bertulang menggunakan bambu pilin ini dimaksudkan guna mengetahui seberapa besar kekuatan beton dalam menahan beban serta mengetahui bagaimana pengaruh pada beton dengan adanya penggunaan bambu pilin tersebut sebagai tulangan. Penggunaan tulangan bambu disini digunakan dua variasi yakni dengan dan tanpa kulit bambu. 


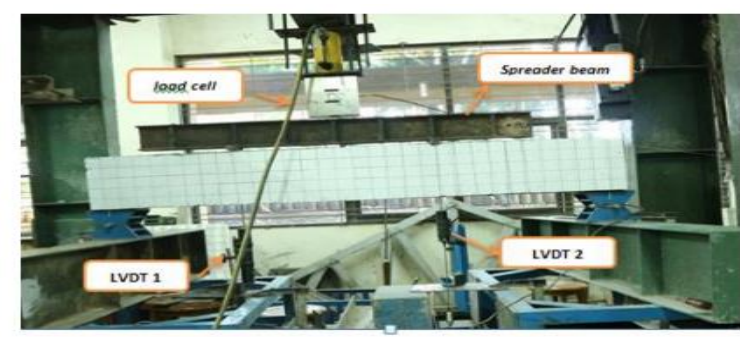

Gambar 1. Sistem Pembebanan Pada Uji Kuat Lentur

Sumber : Gambar penelitian pengujian kuat lentur

Pada benda uji beton berukuran $18 \times 25 \times 160 \mathrm{~cm}$ diuji sebagai balok sederhana (2 tumpuan) dengan tumpuan sendi dan roll. Sistematika uji lentur balok ini adalah dengan memberikan beban terpusat pada balok beton dengan jarak $60 \mathrm{~cm}$, dari beban tersebut akan menghasilkan nilai beban dan nilai lendutan yang terjadi pada balok. Beban yang digunakan adalah menggunakan hydraulick jack yang disalurkan oleh load cell dan disebarkan menggunakan spreader beam sehingga dari situ akan muncul nilai bebannya.

Tabel 1. Beban Maksimum pada Balok Beton

\begin{tabular}{|c|c|c|}
\hline \multirow{2}{*}{$\begin{array}{c}\text { Benda } \\
\text { Uji }\end{array}$} & \multicolumn{2}{|c|}{ Pengujian Lentur } \\
\cline { 2 - 2 } & P maks (Kg) & $\begin{array}{c}\text { P max rata-rata } \\
(\mathrm{Kg})\end{array}$ \\
\hline A1B1 & 3800 & 3400 \\
\hline A1B2 & 3000 & \multirow{2}{*}{2400} \\
\hline A2B1 & 2400 & \\
\hline A2B2 & 2400 & \\
\hline
\end{tabular}

Sumber : Hasil perhitungan pengujian kuat lentur

Dari Tabel 1. diatas terlihat bahwa pada balok A1B1 dapat menahan beban maksimum sebesar $3800 \mathrm{~kg}$, dan untuk beban maksimum terendah terjadi pada balok tanpa kulit sebesar $2400 \mathrm{~kg}$. Hasil uji lendut maksimum pada tengah masing-masing benda uji balok, ditunjukkan pada Tabel 2.

Tabel 2. Hasil Pengujian Lentur

\begin{tabular}{|c|c|c|c|}
\hline \multirow{2}{*}{$\begin{array}{c}\text { Benda } \\
\text { Uji }\end{array}$} & \multirow{2}{*}{ P Maks } & \multicolumn{2}{|c|}{ Lendutan (mm) } \\
\cline { 3 - 4 }$(\mathrm{Kg})$ & Titik 2 & Titik 1 \\
\hline A1B1 & 3800 & $-13,75$ & -5 \\
\hline A1B2 & 300 & $-13,09$ & $-5,17$ \\
\hline A2B1 & 2400 & $-2,67$ & $-0,94$ \\
\hline A2B2 & 2400 & $-2,96$ & $-1,12$ \\
\hline
\end{tabular}

Sumber : Hasil perhitungan pengujian kuat lentur 
Pada Tabel 2. Lendutan terbesar terjadi pada benda uji balok A1B1 tulangan pilinan dengan kulit dengan nilai P maks 3800, sedangkan lendutan terkecil terjadi pada benda uji Balok A2B1 tulanngan pilinan tanpa kulit dengan nilai P maks $2400 \mathrm{Kg}$.

Grafik 5. Hubungan Beban dengan Lendutan

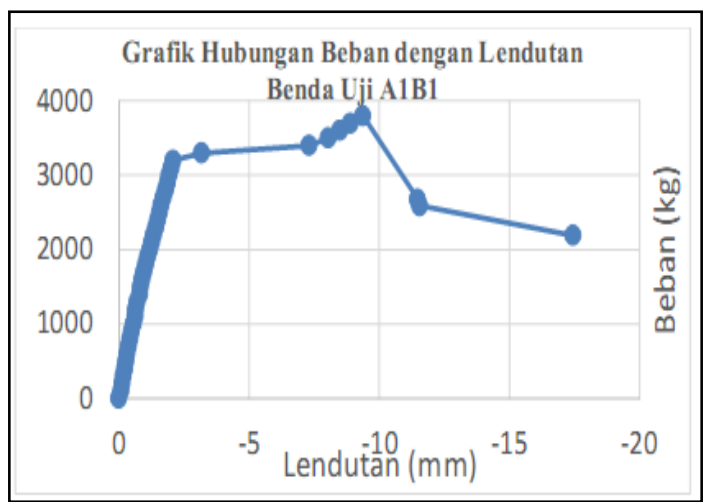

Grafik Benda Uji A1B1

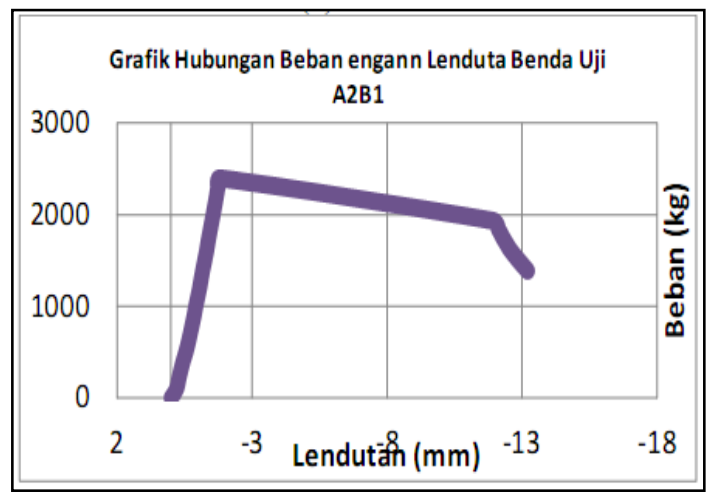

Grafik Benda Uji A2B1

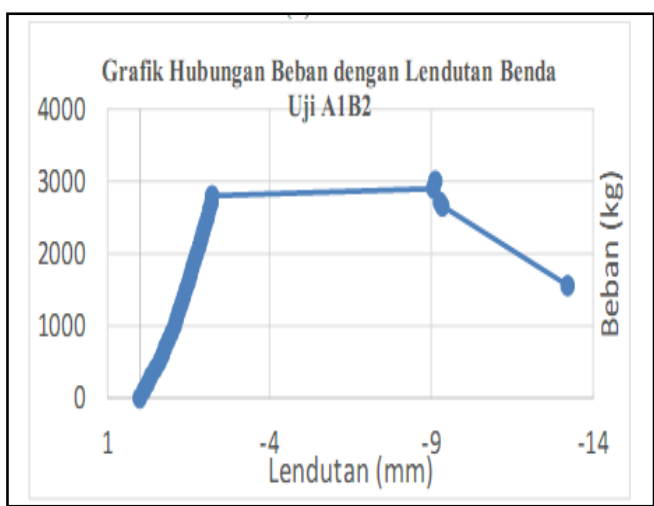

Grafik Benda Uji A1B2

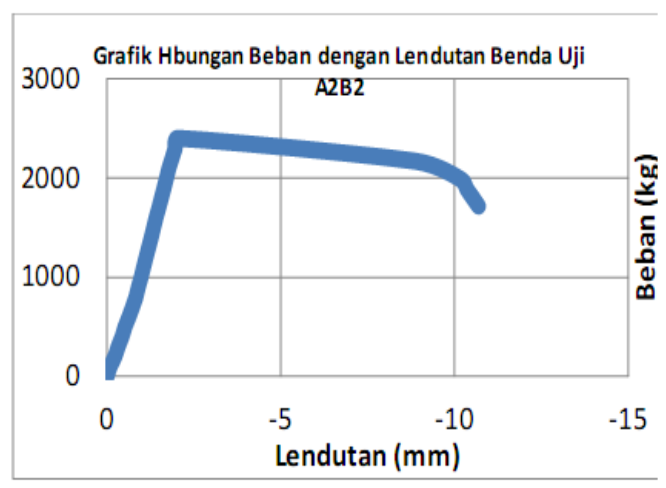

Grafik Benda Uji A2B2

\section{Sumber : Hasil perhitungan pengujian Lendutan}

Pada Grafik 5. terlihat hasil pengujian pada penggunaan tulangan bambu dengan dan tanpa kulit memperlihatkan adanya sebuah perbedaan besar, itu baik terjadi pada beban ataupaun lendutan maksimum.

Grafik 5. Hasil gabungan hubungan Beban dengan Lendutan 


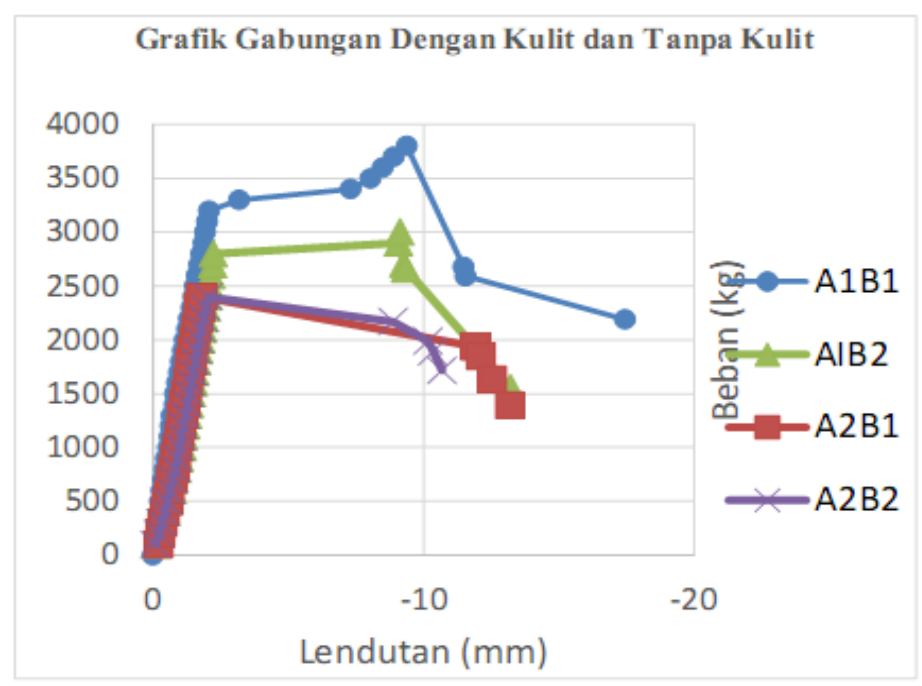

Sumber : Hasil perhitungan pengujian Lendutan

Dari grafik diatas terlihat hasil gabungan pada penggunaan tulangan bambu dengan dan tanpa kulit memperlihatkan adanya sebuah perbedaan besar, itu baik terjadi pada beban ataupaun lendutan maksimum. Pengaruh penggunaan tulangan bambu berkulit begitu pengaruh. Dengan penggunaan tulangan bambu berkulit hasil dari beban dan lendut maks menjadi besar, dengan hasil rerata yakni $3400 \mathrm{~kg}$. Tetapi hal yang berbeda terjadi pada penggunaan tulangan bambu tanpa kulit dengan nilai rerata yakni $2400 \mathrm{~kg}$. Ini membuktikan bahwa dengan adanya penggunaan tulangan bambu berkulit dapat menambah nilai kekuatan pada balok, serta penggunaan bambu berkulit lebih mampu menahan beban lentur yang terjadi pada balok karena pada dasarnya bambu sendiri memiliki sifat lentur.

\subsection{Perhitungan Pengaruh penggunaan tulangan bambu berkulit terhadap P maks lentur}

Perhitungan perbandingan hasil $\mathrm{P}$ maks dapat di hitung dengan persamaan:

Kapasitas dengan kulit :

Nilai $\mathrm{A} 1=\mathrm{A} 1 \mathrm{~B} 1+\mathrm{A} 1 \mathrm{~B} 2$

$=3800+3000$

Nilai $A 2=A 2 B 1+A 2 B 2$

$=2400+2400$

Presentase $=\underline{\mathrm{A} 1-\mathrm{A} 2} \times 100 \%$

A1

$$
=\frac{6800-4800}{\mathrm{~A} 1} \times 100 \%
$$

Dari hasil perhitungan diatas, didapatkan nilai presentase P maks uji kuat lentur pada tulangan bambu pilin dengan kulit dan tanpa kulit sebesar 29,41\%. 


\subsection{Pola Retak Betulangan Bambu Pilin}

Pada pengamatan pola retak ini digunakan guna untuk mengetahui bagaimana hubungan antara pola retak terhadap beban maksimum yang mampu ditopang oleh balok. Hubungan pada pola retak dilakukan dengan mengelompokkan dari hasil pola retak dari keseseluruhan benda uji menjadi satu rerata dari penggunaan tulangan dengan dan tanpa kulit bambu. Disamping dari hal diatas pengamatan nin juga berguna untuk mengetahui bagaimana terjadinya keretakan serta perilaku keretakan pada balok, pengamatan ini dilakukan pada setiap peningakatan beban. Jika terjadi keretakan maka pada balok tersebut diberi tanda sesuai dengan penggunaan beban.

Tabel 6.Hasil pengamatan pola retak pada balok

\begin{tabular}{|c|c|c|c|}
\hline Benda Uji & $\begin{array}{c}\text { Lebar } \\
\text { Retak } \\
(\mathrm{mm})\end{array}$ & $\begin{array}{c}\text { panjang Retak } \\
\text { Depan (cm) }\end{array}$ & $\begin{array}{c}\text { Panjang Retak } \\
\text { Belakang (cm) }\end{array}$ \\
\hline A1B1 & 11,537 & 23,5 & 25 \\
\hline A1B2 & 12,038 & 26,3 & 25,5 \\
\hline A2B1 & 11,388 & 26,6 & 26,6 \\
\hline A2B2 & 14,259 & 24,5 & 25,5 \\
\hline
\end{tabular}

\section{Sumber : Hasil Pengamatan pola retak}

Pada Tabel 6. Hasil dari pengamatan pola retak yang terjadi disetiap benda uji dari A1B1, A1B2, $\mathrm{A} 2 \mathrm{~B} 1, \mathrm{~A} 2 \mathrm{~B} 2$.

Bentuk polake retakan terhadap uji kuat lentur

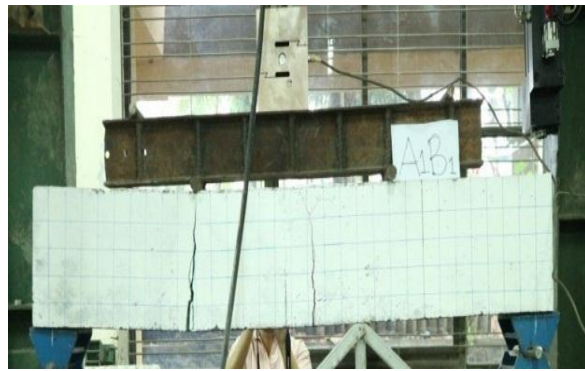

(a) Balok A1B1

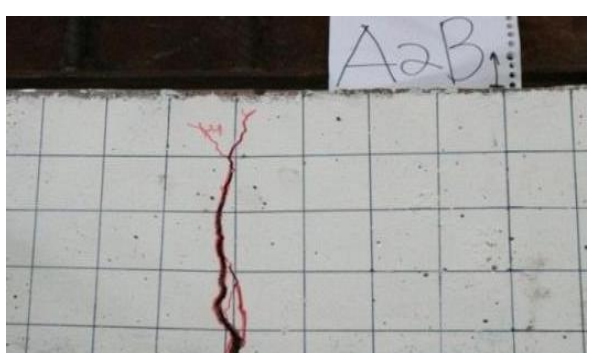

(c) Balok A2B1

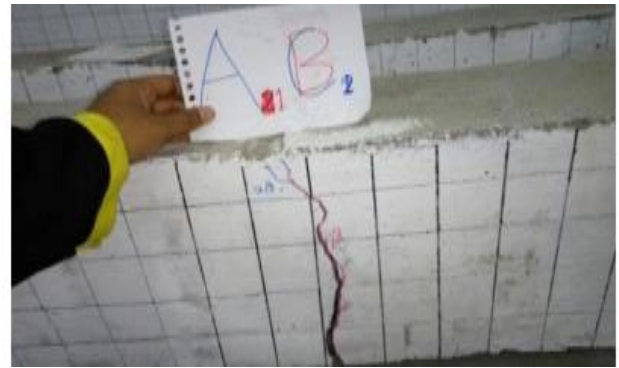

(b) Balok A1B2

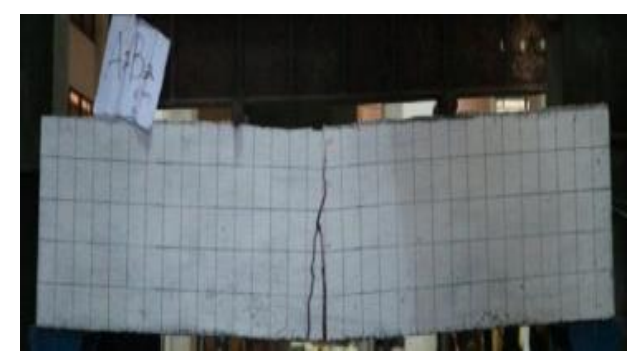

(d) Balok A2B2 
Gambar 2. PolaRetak (a) Balok A1B1 (b) Balok A1B2 (c) Balok A2B1 (d) Balok A2B2

Dari gambar diatas menunjukkan hasil polaretak uji kuat lentur.Pola retak pada benda ujivariasi kulit dan tanpa kulit menunjukkan hasilyang relatif sama.Retak diawali pada kondisi elastis dengan kondisi retak lentur geser dan mengalami keruntuhan lentur. Setelah retak awalpada kondisielastis,kemudian dilakukan penambahan beban akan mengalami penambahan retak sampai balok mengalami runtuh saat kondisi P dalam keadaan maksimum.

\section{KESIMPULAN}

1. Pada pengamatan 4 sampel uji didapati bahwa pada keempat sampel tersebut memiliki pola keretakan yang sama, yakni keretakan diawali pada kondisi elastic dengan kondisi retak lentur geser dan mengalami keruntuhan lentur. Pada variasi dengan kulit memiliki lebar retak rata-rata sebesar $11,78 \mathrm{~mm}$ dan panjang retak $24,97 \mathrm{~mm}$. Sedangkan pada variasi tanpa kulit memiliki lebar retak rata-rata sebesar $12,82 \mathrm{~mm}$ dan panjang retak rata-rata sebesar $25,55 \mathrm{~mm}$.

2. Pada benda hasil uji menggunakan beban $2400 \mathrm{~kg}$ rata-rata nilai lendutan pada penggunaan kulit adalah 1,706 mm serta pada penggunaan tanpa kulit nilainya 1,998 mm. Namun, pola retak dan lebar retak menunjukkan hasil yang sama. Ini menunjukkan bahwa pada kondisi beban yang sama pada kedua variasi menunjukkan hasil yang berbeda

\section{SARAN}

Dari hasil pengujian terlihat bahwa dari penggunaan tulangan bambu pilin berkulit didapati hasil yang cukup baik dari segi kelenturan, serta ini juga bisa menjadi salah satu alternatif terbaru dalam dunia konstruksi dengan sumberdaya terbarukan. Namun walaupun demikian penulis tau akan banyaknya kekurangan pada penelitian ini, diharapkan pada penelitian lebih lanjut mengenai hali ini perlu adanya perhatian yang lebih detail mulai dari proses pemilinan, pemilihan bambu, proses pengecoran serta pada saat pemadatan.

\section{UCAPAN TERIMAKASIH}

Dalam penyusunan artikel ini, penulis ucapkan terimakasih kepada dosen pembimbing dan Universitas Kadiri. Penulis berharap agar artikel ini dapat bermanfaat bagi pembaca.

\section{DAFTAR PUSTAKA}

[1] D. Setyawan, F. Saleh, and H. Payuda, "Pengaruh Variasi Penambahan Abu Ampas Tebu Terhadap Flowability Dan Kuat Tekan Self Compacting Concrete," J. Rekayasa Sipil, vol. 12, no. 2, p. 111, 2016, doi: 10.25077/jrs.12.2.111-120.2016. 
[2] T. Wonlele, S. M. Dewi, and S. Nurlina, "Penerapan bambu sebagai tulangan dalam struktur rangka batang beton bertulang," Rekayasa Sipil, vol. 7, no. 1, pp. 1-12, 2013.

[3] A. I. Candra, H. Wahyudiono, S. Anam, and D. Aprillia, "KUAT TEKAN BETON Fc' $21,7 \mathrm{MPa}$ MENGGUNAKAN WATER REDUCING AND HIGH RANGE ADMIXTURES," J. CIVILA, vol. 5, no. 1, pp. 330-340, 2020.

[4] T. P. G. A, Y. C. S. P, S. Winarto, and A. I. Candra, "PERBANDINGAN KEKUATAN BETON DENGAN CAMPURAN DRAMIX STEEL FIBER DAN TULANGAN WIREMESH PADA RIGID PAVEMENT,”Jurmateks, vol. 1, no. 2, pp. 313-324, 2018.

[5] M. Al Asyari, Y. C. S. P, and S. Winarto, "ANALISA PLAT KONVENSIONAL DENGAN PLATE FLATES PADA GEDUNG BPN KOTAMADYA MALANG,” Jurmateks, vol. 1, no. 2, pp. 259-269, 2018.

[6] S. Sebayang, "Diktat Bahan Bangunan," Bandar Lampung, 2000.

[7] F. P. Pane, H. Tanudjaja, and R. S. Windah, "Pengujian Kuat Tarik Lentur Beton Dengan Variasi Kuat Tekan Beton,” J. Sipil Statik, vol. 3, no. 5, pp. 313-321, 2015.

[8] A. I. Candra, E. Gardjito, Y. Cahyo, and G. A. Prasetyo, "Pemanfaatan Limbah Puntung Rokok Filter Sebagai Bahan Campuran Beton Ringan Berpori," UKaRsT, vol. 3, no. 1, p. 82, 2019, doi: 10.30737/ukarst.v3i1.365.

[9] A. I. Candra, A. Yusuf, and A. R. F, "Studi Analisis Daya Dukung Pondasi Tiang Pada Pembangunan Gedung Lp3M Universitas Kadiri,” J. CIVILA, vol. 3, no. 2, p. 166, 2018, doi: $10.30736 /$ cvl.v3i2.259.

[10] E. Gardjito, A. I. Candra, and Y. Cahyo, "Pengaruh Penambahan Batu Karang Sebagai Substitusi Agregat Halus Dalampembuatan Paving Block," UKaRsT, vol. 2, no. 1, p. 35, 2018, doi: 10.30737/ukarst.v2i1.374.

[11] E. Gardjito, A. I. Candra, and Y. Cahyo, "PENGARUH PENAMBAHAN BATU KARANG SEBAGAI,” pp. 36-42.

[12] A. Pujianto, H. Prayuda, B. C. Zega, and B. Afriandini, "Kuat Tekan Beton dan Nilai Penyerapan dengan Variasi Perawatan Perendaman Air Laut dan Air Sungai," Semesta Tek., vol. 22, no. 2, pp. 112-122, 2019, doi: 10.18196/st.222243.

[13] S. F. Romadhoni, A. Ridwan, S. Winarto, and A. I. Candra, "STUDI EXPERIMEN KUAT TEKAN BETON DENGAN MEMANFAATKAN LIMBAH KERAMIK DAN BATA MERAH,”Jurmateks, vol. 2, no. 1, pp. 86-95, 2019.

[14] I. A. Sucahto, H. R. Agustapraja, and B. Damara, "Pemanfaatan Limbah Tempurung Kelapa Sebagai Campuran Paving Block (Ditinjau Dari Kuat Tekan dan Resapan Air),” Ukarst J. Univ. Kadiri Ris. Tek. Sipil, vol. 4, no. 1, pp. 2579-2581, 2020.

[15] S. Winarto, "PEMANFAATAN SERAT IJUK SEBAGAI MATERIAL CAMPURAN 


\section{DALAM BETON UNTUK MENINGKATKAN KEMAMPUAN BETON MENAHAN} BEBAN TEKAN Studi Kasus: Pembangunan Homestay Singonegaran Kediri,” UKaRsT, vol. 1, no. 1, pp. 1-38, 2018.

[16] Badan Standardisasi Nasional, "SNI 15-7064-2004 Semen portland komposit," 2004.

[17] E. Gardjito, "Pengendalian Mutu Beton dengan Metode Control Chart (SPC) dan Process Capability (SIX-SIGMA) Pada Pekerjaan Konstruksi,” UKaRsT, vol. 1, no. 2, 2017.

[18] F. Akbar, A. Ariyanto, M. Eng, ) Bambang Edison, and S. Pd, "Penggunaan Tempurung Kelapa Terhadap Kuat Tekan Beton K-100,”J. Mhs. Tek. 2014 - e-journal.upp.ac.id, vol. 1, no. 1, pp. 1-11, 2014.

[19] M. Mulyati and A. Adman, "Pengaruh Penambahan Cangkang Kemiri dan Sikacim Concrete Additive terhadap Kuat Tekan Beton Normal," J. Tek. Sipil ITP, vol. 6, no. 2, pp. 38-45, 2019, doi: 10.21063/jts.2019.v602.01.

[20] A. D. Krisna, S. Winarto, and A. Ridwan, "PENELITIAN UJI KUAT TEKAN BETON DENGAN MEMANFAATKAN LIMBAH AMPAS TEBU DAN ZAT ADDITIF SIKACIM BONDING ADHESIVE,” Jurmateks, vol. 2, no. 1, pp. 1-15, 2019.

[21] A. Ridwan and A. Chandra, "Jobmix beton mengunakan pasir lumajang dan penambahan additive masterpozzolith ${ }^{\circledR}$ 402r," J. CIVILA, vol. 3, no. 2, pp. 192-197, 2018. 